\title{
THE DEVELOPMENT OF CREATIVE INDUSTRIES: THE CASE OF LITHUANIAN FASHION DESIGN COMPANIES
}

\author{
Mindaugas Laužikas \\ International Business School at Vilnius University \\ Sauletekio av. 22, LT-10225 Vilnius, Lithuania \\ E-mail:mindaugas.lauzikas@gmail.com \\ Rasa Mokšeckienè \\ International Business School at Vilnius University \\ Saulètekio av. 22, LT-10225 Vilnius, Lithuania \\ E-mail: rasa.mokseckiene@tvm.vu.lt
}

Pateikta 2013 m. liepos 25 d.; parengta spausdinti 2014 m. gegužès 25 d.

doi:10.13165/SMS-14-6-1-03

\begin{abstract}
The analysis of creative industries and, in particular, the specificity of managing creative companies require not only understanding of concepts, such as the creativity, arts and business, but also understanding of creative industries in a broader sense, which varies from one country to another; thus, to get a comprehensive image of creative industries, various classifications, activities and further development possibilities should be examined. There should be the international trade in creative goods and services and its added-value scrutinized. A proportionally large part of this publication is oriented to the analysis of data regarding the demand for arts in global markets and the international trade, as well as the evaluation of contributions of arts to economy, its profitability, regional growth trends, employment and increasing competition among local companies. The research question of the present article is as follows: are development and management of companies that belong to creative industries efficient, and what
\end{abstract}


specific management characteristics could be identified among Lithuanian fashion design companies? To get pertinent research results, a descriptive qualitative study was selected with semi-structured interviews in use to better understand respondents and to obtain more and deeper information on management-related questions.

Keywords: development, creative industries, fashion design companies.

\section{Introduction}

The scientific literature on development peculiarities of creative industries and the creative economy on the whole is well-established. It is important to interpret ideas of authors, such as Colmer ${ }^{1}$, Wolfflin ${ }^{2}$, Burckhardt ${ }^{3}$, Panofsky and Heckscher ${ }^{4}$, Caves ${ }^{5}$, Parrish $^{6}$, Eikhof and Haunschild ${ }^{7}$, McNeilly $^{8}$, Levin ${ }^{9}$, Van den Berk ${ }^{10}$ and many others. In addition, the creativity-related skills and talents that lead to an intellectual property, material wealth and new jobs are described as creative industries in the Strategy for the Promotion and Development of Creative Industries of the Republic of Lithuania ${ }^{11}$. The sector of creative industries is mainly built from small businesses and non-profit organizations that represent public interests. Within this strategy, it is specified that Lithuanian creative industries include handicrafts, architecture, design, film, video arts, publishing, visual arts, applied arts, music, software and computer services, radio and television programs, broadcasting, advertising, performing arts and other areas where cultural and economic aspects of business are connected ${ }^{12}$.

The concept of creative industries is interpreted differently across different literature sources. For instance, in the important United Kingdom's paper "Creative Industries Mapping Document" creative industries are defined as "activities, based

1 Colmer, J. E.M. Forster: The Personal Voice. Routledge, 1975, p. 243.

2 Wolfflin, H. Classic Art: An Introduction to the Italian Renaissance. London: Phaidon, 1994, p. 294.

3 Burckhardt, J. Civilization of the Renaissance in Italy. Random House Publishing Group, 1995, p. 432.

4 Panofsky, E.; Heckscher, W.S. Three Essays on Style. Edited by Irving Lavin. Cambridge: MIT Press, 1997, p. 245.

5 Caves, R. E. Creative Industries: Contracts between Art and Commerce. Harvard University Press, 2001, p. 19.

6 Parrish, D. Marškinèliai ir kostiumai. Kūrybinio verslo vadovas. Liverpool, 2005.

7 Eikhof, D. R.; Haunschild, A. Lifestyle Meets Market: Bohemian Entrepreneurs in Creative Industries. Creativity and Innovation Management. 2006, 3 (15): 234-241.

8 McNeilly, M. Sun Tzu karo menas lyderiams. Pergales strategija. Kaunas, 2007, p. 248.

9 Levin, J. Bohemia in America, 1858-1920. Stanford University Press, 2010, p. 469.

10 Van den Berk, T. Jung on Art: On the Autonomy of the Creative Drive. Routledge, 2012, p. 176.

11 Lietuvos Respublikos Kultūros ministerija. Kürybiniu industriju skatinimo ir plètros strategija. Vilnius. 2009.

Ibid. 
on an individual creativity, skills and talents, that are capable of creating a material wealth and jobs via the application of an intellectual property"13. Creative industries in Europe is considered as a cultural policy which promotes production and consumption of cultural goods and services.

Makselis ${ }^{14}$ emphasized the Adorno's opinion (the fifth decade of the 20th century) that creative industries are oriented to a massive consumption, for instance, radio and television or Hollywood at the extreme level). Apart from differently understood concepts and terms related to creative industries, countries possess a different understanding about creative sectors, such as design, publishing, architecture, etc. To clarify these contradictions, in 2006 the European Commission delivers the research on the creative economy in Europe, where the detailed classification of creative industries is presented.

Based on the historical and conceptual analysis, Rimkute ${ }^{15}$ in her paper examined the concepts of cultural and creative industries. The author distinguished, quoting Ratzenbök, that these industries are among the most promising for economic policies, such as the information technology and biotechnology. However, many authors believe that there is still no consensus on what those terms mean. The author presented definitions of both creative industries and cultural industries in the context of development and evolution. The cultural industry is defined as a standardized system producing cultural objects in large quantities under the influence of the capitalism monopoly: the mass culture becomes identical, and the skeleton starts emerging as a factory-made structure ${ }^{16}$. For a long time, it was considered that a cultural heritage and professional arts are important fields for the public, while those areas that could not be used commercially did not receive attention of policy makers. On the other hand, in today's global world cultural industries cover such areas that are funded by the State.

Creative industries provide products and services that are associated with the cultural, artistic, or simply entertainment value. Gray ${ }^{17}$ emphasizes the role of the state's support for culture, as it is the heritage for future generations, a national identity and prestige, benefits for local economies, contributions to a humanitarian education, innovations, and creativity. Rimkute ${ }^{18}$ concludes that both creative and cultural industries include the same fields; thus, cultural industries should get enough of the public support, because they are 'public goods' and creative industries

13 Rimkute, A. Kultūros politika ir kultūros industrija: tradicinis santykis ir nauji iššūkiai. Respectus Philologicus. Central and Eastern European Online Library. Vilnius, 2009, 15 (20): 62-75.

14 Makselis, R. Lietuvos kultūros įstaigų valdymas kūrybinių industrijų plètojimo pagrindu. Šiuolaikinis kultūros įstaigų administravimas ir valdymas. Vilnius, 2007: 93-130.

15 Rimkute, A., supra note 13.

16 Ibid.

17 Gray, Ch. M.; Heilburn, J. The Economics of Art and Culture. Cambridge: University Press, 2001, p. 1-10.

Rimkutè, A., supra note 13. 
can survive in conditions of the market economy, because the essence of their development is creativity.

The term 'Creative Industries' varies from country to country. For the first time, this term appeared in Australia in 1994, which was expanded and was started to be used in the United Kingdom in 1997. The United Kingdom is one of the most advanced countries in the field of creative industries, where in 1998 the Map of Creative Industries was developed, which led to a great number of researches and similar maps of creative industries prepared worldwide.

Makselis ${ }^{19}$ presents the cases of creative industries in the UK, Austria, Sweden, where in 2001 the Great Britain's studies on creative industries reflected a very strong development of the country in this area, while the main focus remained on London and South-east England. Studies have also shown excellent results of creative industries' exports, i.e. the global demand for products created in Great Britain. The research of creative industries in Sweden was conducted in 2004, when the concept of Creative Industries was defined as the Experience Industry, a term, which described people of creative professions and their businesses, which main goal was creation of experience and/or rendering experience in various forms. Thus, the Swedish industries are related to the development of higher-level needs regarding the culture, hence, dreams, feelings, needs, when some people use the culture and arts in order to feel better. The Map of Creative Industries in Austria was drawn up in 2006; it provides a three-sector model including private, non-profit and public sectors. The creative industries sector in this country is a very fast growing sector, where architecture, advertising, etc., deliver a great economic benefit.

Information technologies led to the development and spread of creative industries, i.e. to reach geographically distant areas of culture and arts due to the efficiency of communication with other economies, wider marketing opportunities, etc. There is also the concept of 'Creative Employees' appearing, where creative employees are identified as scientists, engineers, university professors, poets and writers, artists, and entertainers. As the outcome of interaction among culture, economics, business and arts, the significance of economic and social aspects in the culture emerges. The term 'Creative Industries' is complex not only because its structure and contents, but also because of the changing businessmen's approach to these industries. Therefore, the research object is the peculiarities of management of creative companies in Lithuania, the case of the Lithuanian fashion design industry is examined.

\section{Creativity and Culture}

Florida ${ }^{20}$ revealed his reflections on the creativity and culture: the culture, based on the creativity, is a crucial factor in stimulating the economic development. Florida

19 Makselis, R., supra note 14.

20 Florida, R. The Rise of the Creative Class: And how It's Transforming Work, Leisure, Community and Everyday Life. New York: Basic Books, 2002, p. 404. 
in his book "The Rise of the Creative Class" believed having found the formula for a healthy economy and prospering city and provided his argumentation: the knowledge-based society requires innovations in stimulating economic growth; countries need the creative class to create innovations; representatives of this class are mainly concentrated in urban areas; $3 \mathrm{~T}$ (tolerance, technology, talent) are necessary conditions to attract creative people to a city. Florida divided the creative class into two groups ${ }^{21}$ : extremely creative people (poets, architects, engineers, university professors, etc.) and creative professionals (who work in the technology industry, business management and corporate finance, etc.).

Creative employees' work results are the intellectual property which could be protected by intellectual property rights and patents. The development of innovations and new technologies, cooperation between the culture and arts and business elucidate the concept of the creative economy, which is related to the creativity, talent, the ability to gain knowledge and education as well as to use the experience in producing cultural goods and services. In order to better understand creative industries, there were several models raised ${ }^{22}$ : the British Model states that the creativity and innovations drive the country's economy, which is related to the development of skills and talents while creating new jobs; the Symbolic Model is a typical model existing in Europe and derives from traditional cultural studies, where the main focus is not on the mass culture; the Concentrated Model accords cultural values to cultural goods and is about the integration of cultural goods and services into production (creative ideas are born in forms, such as audio, text, image, and in this context are spreading in the cultural and commercial environment, thereby, departing one from another); the Copyright Model is based on the directly or indirectly tackled creativity, trade, manufacturing, distribution and copyright.

In the Trade and Development Conference 2004, organized by the United Nations, the concept of creative industries was extended from arts activities to economic intellectual property-intensive activities. Traditional creative activities, such as performing arts, visual arts, were separated from activities, such as advertising, media that are closer to business, resulting in a greater number of creative industries sub-sectors. In 2006, there was the study on the economy of culture and creative industries initiated by the European Commission with the recommendation to integrate creative industries into the Lisbon strategy.

Creative industries are the centre of the creative economy, thus, to describe creative industries it should be added that it is like the intersection between arts, culture, business and technologies; all what creates a cycle of the creativity is a wide range of different sectors: folklore, festivals, music, books, paintings, visual arts, technology sub-sectors, such as the film industry, television, video games, and service sectors, such as the architecture, design, advertising, etc. In 2008 and 2010, in the 
study "Creative Economy", creative industries were divided into four broad groups that were broken down into nine subgroups ${ }^{23}$ (see Figure 1).

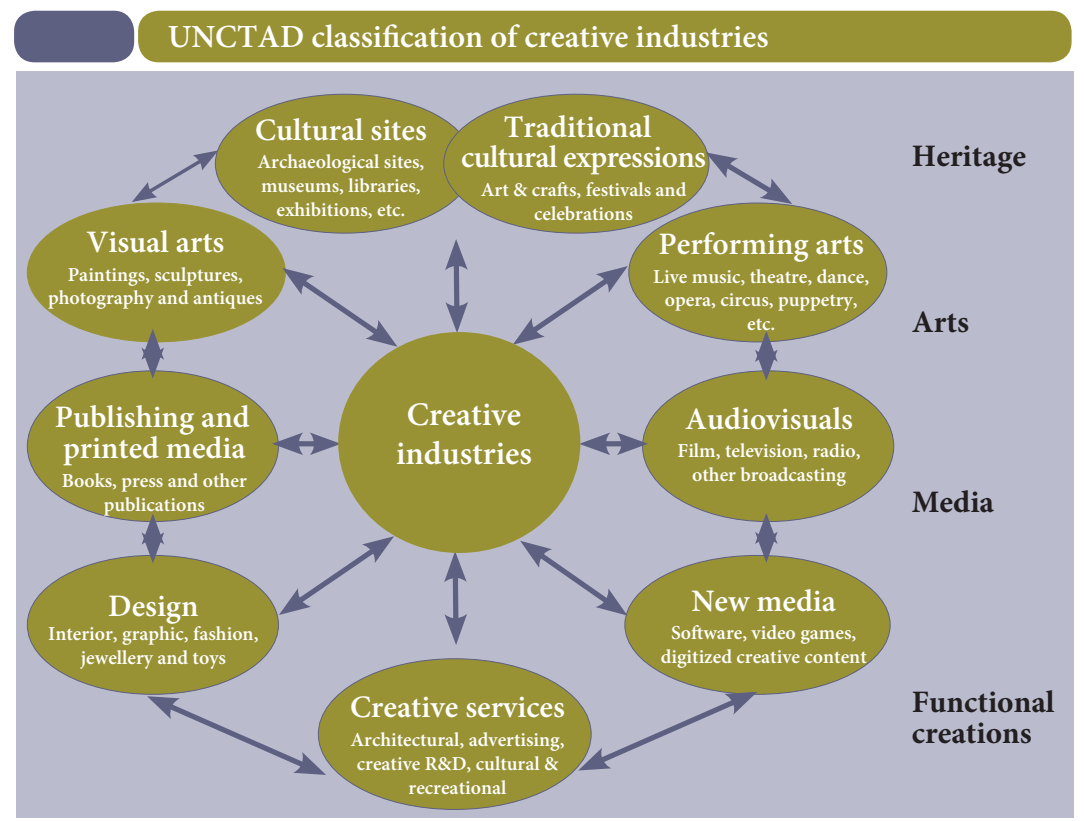

Source: United Nations. Creative Economy. Report [interactive]. 2010, p. 8 [accessed on 2011-01-22]. $<$ http://www.unctad.org/en/docs/ditc20082cer_en.pdf $>$.

Figure 1. UNCAD classification of creative industries

1. Heritage: heritage identifies origin of all forms of arts and 'spirit' because it is like acknowledgement and expression of the culture and traditions. Heritage has two subgroups:

1.1. Traditional cultural expression: arts, crafts, festivals, celebrations;

1.2. Local culture: archaeological, museums, libraries and exhibitions.

2. Arts: this group is based on arts and culture and is composed of two subgroups:

2.1. Visual arts: painting, sculpture, photography, vintage items;

2.2. Performing arts: live music, theatre, dance, opera, circus, puppet theatre.

3. Media: the target is to reach a maximum range of audiences; it is combined of two sub-sectors:

3.1. Publishing and printing: paper, printing, publications;

3.2. Audio-visual arts: film, TV, radio. 
4. Functional works: its focus is on the development of services and is divided into three subgroups:

4.1. Design: interior design, graphics, fashion, jewellery, toys;

4.2. The new media: video games, software, digital content creation;

4.3. Creative services: the architecture, advertising, culture and entertainment (recreation), creative research.

According to the feasibility study "Creative Economy 2008-2010"24, the trade analysis is based on this classification, but there are still a small number of countries classifying creative industries in such way. Therefore, as it is stated in the feasibility study, there is no either correct or incorrect model; it provides such distribution of creative industries and identifies global trends of creative industries' development within the international trade by sector. The importance of arts to business and economy is also interpreted in different ways in different scientific literature sources, legislation, and statistical data sets. Similarly, the Lithuania's progress in terms of creative industries' development and operating mechanism is interpreted specifically.

The fact that creative industries play an important role in Lithuania is witnessed in the feasibility study ${ }^{25}$, which provides the data regarding the business growth during the period 2006-2007 of $8 \%$ and the growth in headcount of $2.8 \%$. It is regrettable that many creative employees are not included and evaluated in terms of economic criteria, and, therefore, we are coming to a relatively low level of entrepreneurship among representatives of culture and arts, i.e. the development of creative industries, business management, accounting and other areas should be supported by ingenious knowledge, skills and information, transferred by technologies to creative industries; it needs further acknowledgement of best practices, and there is no systematically applied State support for creative industries. The development of creative industries is also influenced by the fact that creative skilled people are concentrated in cities, thus, alternative economic activities in rural areas are quite fragmented. To continue, developers pay too little attention to marketing, as the result of which the competitiveness of creative products and services in the country and worldwide decreases. The reduced competitiveness leads to the brain drain of creative employees.

Lithuania has not fully developed an appropriate approach regarding creative industries, although the majority of Lithuanian companies are considered as small and medium-size, because the public does not understand that arts and business can mutually cooperate. Driven by this purpose, there were maps of creative industries initiated in Lithuania and other European Union countries that were as inventories of creative industries, reflecting the performance of companies engaged in creative activities, business operations, prospects, progress, cooperation, etc. The first work of this nature (the analysis of contributions of creative activities to the Lithuanian economy), where the creative industries sector is identified as a very important

24 United Nations. Creative Economy. Report 2010. UNCTAD/DITC/TAB, 2010, and supra note 22.

25 Antanavičiūtè, R., et al. Lietuvos kūrybinès ir kultūrinès industrijos. Galimybių studija. Vilnius. 2008, p. 91. 
branch having a great development potential (particularly for small and medium businesses), was conducted by Starkevičiūte ${ }^{26}$. In her conclusions, she states that creative work creates a higher added-value and a longer-term competitive advantage, provides preconditions for a faster income growth, thus, it is obvious that Lithuania's economic policies should encourage more creative than technical work, enabling the increase in the share of creative work within the economy ${ }^{27}$. Other similar works are maps of creative industries of Utena and Alytus counties, led by Prof. Dr. Mažeikis.

It gets obvious that companies executing creative industries-related activities, particularly in Lithuanian peripheries, do not identify their creative activities as basic activities; they avoid competition, so it is important to develop, promote and provide an adequate State financial assistance and necessary conditions to extend the range of creative activities and opportunities to participate in various projects. It is important to have creative talented people that make living from their skills, and business people perceiving them as partners. A good example is the Arts Printing House, which hosts a variety of activities from theatre to dance and/or other events; there could be more similar incubators of arts, where country's creators could introduce their products, established. Notwithstanding obstacles, there are some visible positive aspects witnessed, such as a diverse cultural heritage, economic growth, growing number of foreign tourists in Lithuania, stronger focus on representation in certain fields of arts (the theatre or publishing) that increase consumption of products and services of creative industries.

The main goals of the Strategy for the Promotion and Development of Creative Industries of the Republic of Lithuania ${ }^{28}$ are the following ones: to provide necessary conditions for the efficient development of creative industries (by using the population's creative potential), the sector's contribution to the economy, for building the knowledge-based economy and increasing the competitiveness of creative industries' production in the country and abroad. The Ministry of Culture underlines the following strategic objectives: to ensure the creativity in the cultural, educational, scientific and economic fields in order to enhance creative industries of Lithuania and to increase the share of these sectors in Lithuania's GDP and employment. It is also expected to carry out the analysis of the Lithuanian creative economy, to facilitate dissemination of information about creative industries online, to expand the network of arts incubators, to perform the analysis of exports of cultural and arts products and services to other markets as well as the feasibility study of its further development.

Creative industries contribute to the maintenance of sustainable equilibrium, because tangible or intangible culture of communities of a particular nation or worldwide must be preserved for future generations, just as natural resources or ecosystems be preserved to ensure human life. Thus, having the main concepts pos kultūros programos centras. Britų taryba. Vilnius, 2003, p. 25. Ibid. 
related to creative industries and further opportunities of enhancing these industries explained, it is necessary to identify the demand for creative industries in the European Union, Lithuania and worldwide ${ }^{29}$.

\section{International Trade in Creative Goods and Services: Lessons That Should Be Learned from the Period 1996-2008}

The global creative economy is constantly growing. In 1990, the annual growth in OECD countries doubled the size of the overall service industry and was four times higher than the manufacturing industry, as it is stated in the United Kingdom's review on cultural and creative industries. The growth of cultural and creative sectors in the European Union from 1999 to 2003 exceeded the overall economy by $12.3 \%$, where the turnover reached 654 billion $€$; in 2003, it was responsible for $2.6 \%$ of GDP in the European Union ${ }^{30}$. The sector employed 5.8 million people, and the growing demand for creative products was clearly felt. One percent of GDP, spent on the household expenditure on recreation and culture, is positively correlating with the income per capita. The richer the country is, the more likely that a higher percentage of income will be accorded to culture and leisure. The UK consumers' expenditure on culture increased from $5 \%$ in 1963 to $7 \%$ in 2008 .

The international trade is the key component of the creative economy; for instance, based on the UNCTAD survey, in recent years the world trade in products and services of creative industries has largely increased: during the period 20002005 the annual average growth was of $8.7 \%$; the world's exports of visual arts have doubled from 10.3 billion \$ in 1996 to 22.1 billion \$ in 2005, while exports of audiovisual arts products have tripled. It is expected that Asia will reach the highest growth among all regions in global entertainment and media industries, reaching a $9.2 \%$ annual growth rate, and China, which will be the fastest growing industry in the world with over $25 \%$ annual growth rate $^{31}$. In light of global changes, the society needs to understand the linkage between cultural and social life and economy, thus, the EU Statistical Office Eurostat for the first time conducted the study of culture in $2007^{32}$.

In 2005, among 27 European Union countries there were 4.9 million people working in sectors related to creative economy, which accounted for $2.4 \%$ of the total employment, based on the study conducted in $2007^{33}$. In general, people employed in the cultural sector have a better education: $48 \%$ of cultural workers are with a higher

29 Lietuvos Respublikos Kultūros ministerija, supra note 11.

30 Creative \& Cultural Skills. Creative and Cultural Industries: Key Facts. UK, b.m. 2010.

31 Ibid.

32 European Commission. Eurostat. Office for Official Publications of the European Communities. Population and social conditions. Cultural Statistics. Luxembourg, 2007, p. 185. Ibid. 
education, compared with $26 \%$ of employees in other sectors. In most member states such as Belgium, Estonia, Lithuania, Spain, more than $60 \%$ of workers in the cultural sector have university education. Analyzing the data of people with higher education employed in the cultural sector and total employment, there is a clear trend regarding the position of higher education in cultural employment witnessed (64\% in Estonia, $63 \%$ in Belgium, etc.). $16 \%$ (Spain, France, etc.) of employees in the cultural sector work in temporary jobs, compared with $13 \%$ of all employees; $25 \%$ (a European leader is the Netherlands with $59 \%$ ) work part-time, compared with $17 \%$ of all employees; $29 \%$ of workers in the cultural sector created jobs themselves or worked in family businesses, compared with $14 \%$ of all employees, the largest number of such employees is in Italy (53 \%), the Netherlands and Greece possess $35 \%$, and the smallest, less than $10 \%$, is in Romania, Lithuania, Estonia, Slovenia; a significant proportion (29\% of cultural employees) work at home: $41 \%$ in Austria and Great Britain, $46 \%$ in Iceland, the lowest percentage is in Lithuania.

The highest percentage of cultural employment in total employment was in the Netherlands $(3.8 \%)$ and the lowest percentage $(1.1 \%)$ was found in Romania. The spread of cultural employment, based on age, shows that the largest employment of culture in Romania is in the age group of 25-49 years (accounts for 76.9\%); the largest proportion of cultural employment in Latvia is in the age group of 15-24 (accounts for $20.2 \%$ ), while the largest cultural employment share in the age group over 49 is in Estonia (accounts for $38.7 \%$ ).

China occupies the leading position among 20 leading exporters of creative goods in the period from 2002 to 2008, while Great Britain, Germany, Italy, the United States, France and the Netherlands lag slightly behind. According to the feasibility study of creative industries in the world trade "Creative Economy" 34 , a similar situation was in the period of 1996-2005. India showed a significant growth in exports of creative products from 2002 to 2008. Exports in creative goods of developed economies grew in the period of 2002-2008 and earned from 128 billion \$ to 227 billion \$. As it is stated in the "Creative Economy" 35 , the largest contribution to the trade equilibrium of goods was made by products of design; the value of exports of art crafts also increased; however, developed economies have lost the market share in this sector, which went to developing economies. Among ten major developed economies in terms of exporting creative goods in 2008 the United States occupied the first place due to its competitive position of design of goods, while in 2005 this position belonged to Italy. Global revenues from cultural and recreational services, that include museums, libraries, etc., increased from 7 billion \$ in 2002 to 11.3 billion $\$$ in 2008. Though the participation rate of developing economies in the services market is low, the largest part of income in Turkey, Malaysia and India come from the cultural services sector. 
The export dynamics of creative goods among developing economies is a new phenomenon in the creative economy, for instance, the China's export growth has been staggering, from 32 billion \$ in 2002 to 85 billion \$ in 2008 (from 18.4 billion \$ in 1996 to 61.3 billion $\$$ in 2005). During the same period, exports of creative goods from developing economies increased from 76 billion $\$$ to 176 billion $\$$ (data tripled in the period of 1996-2005). Asian economies account for more than three-quarters of the total export growth in creative products from Southern regions, where the main growth during the 2002-2008 was not only in China, but also in the Southern and Western Asia. Exports in creative goods in Latin America and in the region of the Caribbean Sea almost doubled in the period of 2002-2008, from c.a. 5.5 billion $\$$ to 9 billion $\$$ (from 3.5 billion $\$$ in 1996 to 8.6 billion $\$$ in 2005), although the volume of exports in these regions, with the potential of creative industries, remained relatively low. The only Mexico in this geographical area is included among the twenty major exporters, while Brazil, Argentina and Colombia are considered important exporters. Exports of creative industries in the entire region of the Caribbean Sea in 2008 amounted to 57 million \$, where the largest exporter in the region was the Dominican Republic (2008), while in 2005, Cuba and Trinidad and Tobago were the most important exporters.

Africa has contributed to the world's total exports of creative products only by $0.6 \%$ although African exports grew from 740 million \$ to 2.2 billion $\$$ in the period of 2002-2008. Egypt was the largest African exporter, followed by South Africa, Tunisia, Morocco, Mauritius (in the period of 2000-2005, the largest exporter was South Africa). In 2008, Egypt reported a large profit from the creative industries sector (the feasibility study "Creative Economy", 2010). Africa's weak performance in global markets is reflected not only in the limited capacity of the continent, but also in the fact that many African creative and cultural products are produced in informal sector, where it is difficult to obtain statistical data.

The data from the world's least developed countries is very limited, but this data shows that the sectors of creative industries are important in countries, such as Cambodia, Mali, Senegal, and Tanzania. A similar situation is in developing countries of small islands. Thus, China is a major exporter in the context of emerging economies, and it is noted that nine out of ten most important exporters of creative goods are also Asian countries. African creative products are under-represented in global markets, regardless an existing creative potential.

In the study "Creative Economy"36 (2010), it is stated that the global economic crisis had a huge impact on the services sector, while income-sensitive sectors, such as tourism, culture and entertainment services, suffered the recession. Services are the key component within the dynamics of the creative economy, playing the growing role in all sectors of creative industries, thus, the creative economy is not limited to arts and culture and is rooted in a variety of interactions, such as among the culture, economics and technology. 
The average annual rate of world's exports of services in the period 2000-2008 was of $13.5 \%$ reaching 3.9 trillion \$ (4 trillion \$ in the period 1996-2005). Creative sectors grew faster than traditional sectors: services exports rose from 62 billion $\$$ in 2002 to 185 billion \$ in 2008 (from 52.2 billion \$ in 2000 to 89 billion $\$$ in 2005). The largest dynamism was experienced in the architectural and advertising services. The annual growth rate in creative services reached $17.1 \%$ in the period from 2002 to 2008 (compared to $11.2 \%$ in the period of 2000-2005). Exports of developed economies accounted for $83 \%$ of total exports of creative services in 2008 (compared to $82 \%$ in 2005), the developing economies reached the share of $11 \%$ (11\% in 2005), and transition economies occupied $6 \%$ of the whole creative market ( $7 \%$ in 2005).

Among all creative services, the architecture, private culture and entertainment were the services that held the strongest trade in world's markets in 2008; a similar situation was in 2005, the United States continued to maintain the leading position in exports of private, cultural and entertainment services in 2008; the most important exporters among emerging economies were Turkey, Malaysia and India. Imports of creative services grew from 72.3 billion \$ in 2002 to 168.7 billion \$ in 2008 (from 43.8 billion \$ in 1996 to 85.7 billion \$ in 2005). Architectural and design services were ranked first, with imports growing from 21.3 billion $\$$ to 63.6 billion $\$$ that accounted for $37.5 \%$ of total imports of creative services (in 2005, it was ranked at the second place, switching from 9.4 billion \$ in 1996 to 23.3 billion \$ in 2005, which accounted for $27.2 \%$ of total imports of creative services). Advertising and marketrelated services grew from 14.1 billion $\$$ to 40.0 billion $\$$, to wit, $24 \%$ of creative services imports in 2008 (from 9.2 billion \$ to 16.9 billion \$, i.e. $19 \%$ of creative services imports in 2005).

Imports of private cultural and recreational services grew from 20 billion $\$$ to 35 billion \$, accounting for $20 \%$ of total imports of these services in 2008 (from 14.8 billion $\$$ to 25.6 billion $\$$, and accounted for $30 \%$ of all of these services imports in 2005.). Imports of audio-visual arts services grew from 12.3 billion to 21.9 billion $\$$, which accounted for $13 \%$ of total imports of creative services in 2008 (from 9.0 billion $\$$ to 16.3 billion $\$$, which accounted for $19 \%$ of total creative services imports in 2005). Thus, it can be concluded that since 1990 in countries of the developed world creative industries were developing much faster than other sectors, and new technologies, especially the multimedia content, telecommunications, digital technologies, had a strong influence on a rapid development of these sectors, because this way was much more efficient to spread and acquaint the public with creations.

The consumer income in growing developed economies, along with changing consumption values of cultural model, helped the creative economy arise. Many countries have been encouraged in terms of employment, innovations, trade and development issues; however, the export leader of creative industries in 2007 were the United States of America, and the overall GDP average in developed countries was $6 \%$ in 2007. The participation of developing countries in the creative economy is different, because it depends on production, export opportunities, etc. Well- 
known artists are also looking for broader opportunities in terms of income and selfpromotion by travelling to various countries.

There is a growing number of emerging countries that study ways to develop the creative economy. Asia leads within these processes, according to the feasibility study "Creative Economy"37 (2010). Some Asian countries from the planned policy identify creative industries as the priority sector in their national development plans. A number of Asian emerging economies are among the growing exporters of several creative products. Some Asian regions, such as the Pacific Asia and the Middle East, are the leaders in creative activities and innovations, such as the media and audio-visual tools, advertising, architecture and digital services. A huge potential for creative industries to grow is in South America, but this process is quite slow because these countries are still learning. The greatest changes are expected in sectors, such as music, festivals or cinema. The creative economy is being developed in both developed and developing economies, it is found as inexhaustible resource. The developed economies are already benefiting from this sector, while the developing economies are just starting to develop the creative economy. Having a look at the review of cultural and creative industries in the $\mathrm{UK}^{38}$ (2010), it is visible that the cultural economy in the United Kingdom, in terms of GDP, is the world's largest cultural economy, which currently employs 678,480 people by creating the GDP of 8.24 billion pounds every year.

Though the employment was growing in all geographical regions of the UK, London remains the centre of cultural and creative industries ( $24 \%$ of employees). As it is stated in the review, employees of this sector are highly skilled workers, and the largest percentage of employees are males (60\%), while $93 \%$ are white workers. Within the review, there is the cultural and creative industries' growth emphasized over the last 20 years, which reads $4 \%$, compared to the rest of the economy (3\%). Exports in 2006 amounted to 16 billion pounds that represent $4.3 \%$ of all exports in goods and services. The report predicted a significant employment growth in cultural and creative industries. $50 \%$ of all British artists are living in London, because this is the place where you can most likely to have recognition. The feasibility study "Creative Economy"39 revealed that the developed economies are still dominant in global markets in trading products of creative industries that generate large profits for these countries; however, not all developing economies are ready to encourage the creativity; for instance, in Africa, despite a great number of creative talents, the creative potential remains untapped. There should be a dialogue, exchange of

37 United Nations. Creative Economy, supra note 24.

38 Department for Culture, Media and Sport UK. Creative Britain - New Talents for the New Economy. 2008; Department for Culture, Media and Sport UK. Creative Industries Economic Estimates. 2010. 
experience among creative industries encouraged. Artists and developers need to create the alliance with the following ${ }^{40}$ :

- $\quad$ Government representatives, public and non-public sectors;

- The private sector, profit-oriented companies and business groups, potential sponsors;

- Lobby groups, federations, associations and unions;

- $\quad$ Non-profit organizations and universities.

Every person is a consumer of creative products, every day we listen to music, read books and newspapers, watch television, movies, go to the theatre, attend arts exhibitions, wear fashionable dresses, etc. The creative economy must be active at the mass level, promoting social inclusion and being adapted to young creative women, elderly people and minorities ${ }^{41}$. Moreover, creative industries are ecology-friendly, because this sector requires more creativity, rather than natural resources.

\section{Creative Industries in Lithuania}

The success in transition of Central and Eastern European countries and strengthening competitive advantages in the European Union was determined not only by advanced technologies, cooperation with emerging markets or introduction of new services and/or products, but also by the creativity and intellectual potential that led to realization of new ideas and created a larger value-added for Lithuania. A creative work creates a higher added-value, provides a long-term competitive advantage and creates prerequisites for a rapid income growth, thus, it is obvious that Lithuania's economic policies should encourage more creative work than technical activities in order to increase the share of creative work in the economy ${ }^{42}$.

In the survey conducted in 2003, which examined the contribution of creative industries to the Lithuanian economy, Starkevičiūtè described the Lithuania's gap in the development of economic activities, compared to other European Union countries, as the gap in the development of new ideas that are in parallel to the country's untapped potential. The emphasis is placed on a narrow understanding of arts in the country (performing arts, music) and a different approach to this sector is proposed, i.e. to describe the creative sector by its contribution to the economy of Lithuania. In preparing this work, the author stressed that the cultural statistics is insufficiently analysed in many countries, including Lithuania; therefore, British scientists' recommendations should be used in Lithuania while executing the study of creative economic activities. According to the author, the Lithuanian Government economic policy was based on tangible investments: a generous fiscal, legal and privatization-based promotion of private investments reduced the State's tax revenues

40 United Nations. Creative Economy, supra note 22, p. 208.

41 Ibid.

42 Starkevičiūtè, M., supra note 26. 
and led to degradation in quality of public services (healthcare, education, culture) and conditions that are not in favour for development of skills and knowledge of the public $^{43}$.

Unfortunately, insufficient attention was paid to new technologies and knowledge that were necessary for a rapidly increasing flow of information, education of culture to make Lithuania more competitive with its existing potential of talented people. Starkevičiūte $\dot{e}^{44}$ notes that Lithuania has learned from mistakes, evaluated scientists' advices and examples of other countries and has distinguished main priorities of developing the knowledge society and accumulating the human capital. However, it faced a new barrier, which was mainly an understanding what the knowledge economy was (it was understood as the country's computerization in Lithuania, the Internet access and an increasing number of students in higher education), and only later Lithuania realized that this was not the way to competitively perform, as an effective competition was via the creative society; the need to innovate was constantly growing, innovations became the only means to survive in conditions of a fierce competition and globalization ${ }^{45}$.

In 2002, the creative sector in Lithuania earned 2.1 billion $€$, which accounted for $2.0 \%$ of the Lithuania's GDP. Makselis ${ }^{46}$ mentioned that in 2002 Lithuania's creative industries employed $4 \%$ of all employees. The largest source of revenue for television was advertising and, according to Starkevičiūte $\dot{e}^{47}$, the advertising market was sensitive to changes in the economy reflecting well the state of the economy and its development trends. While scrutinizing the growth in a number of users, it is related to volumes of advertising and vice versa. The map of creative industries of Utena's and Alytus' counties, prepared in 2005 by Prof. Dr. Mažeikis with the support of the British Council, showed that the situation in these regions was different: there were 445 organizations of creative industries in Utena, and there were 544 entities in Alytus. The study revealed that the development of creative industries in Lithuania is strongly influenced by geographical conditions, infrastructure and traditions.

This study encouraged the preparation of the Strategy of Promotion and Development of Creative Industries in Lithuania ${ }^{48}$ (developed in 2009), where the strategic goal was to contribute to creative industries as promising and innovative areas that were important for the country's economy and society, as well as to encourage the competitiveness of products and services of creative industries in

43 Starkevičiūtè, M., supra note 26.

44 Ibid.

45 David, P. A.; Foray, D. An Introduction to the Economy of the Knowledge Society. International Social Science Journal. 2002, 54 (171): 9-23.

46 Makselis, R., supra note 14.

47 Starkevičiūtè, M., supra note 26.

48 Lietuvos Respublikos kultūros ministerija, supra note 11. 
native and global markets ${ }^{49}$. Like many countries worldwide, the European Union (including Lithuania) promotes creative industries by providing means of financial support, public education, encouraging the youth creativity and cooperation of cultural and arts sectors with business.

In 2008, in order to implement the Lithuanian Cultural and Creative Industries Program, the Lithuanian authors of the feasibility study tried to prove that it would contribute to the Lithuania's competitiveness, added-value, innovations, absorption of EU structural funds, rapid integration into other cultural structures, and country's economic growth. The growth potential of creative industries encouraged to look at Lithuanian higher education institutions' needs to improve the system of trainings and education, to promote co-operation of arts, sciences, education and business, thus, within the feasibility study ${ }^{50}$ there were not only science and higher education institutions involved, but also businesses, creative communities and incubators of arts.

In order to identify limits of the creative and cultural economy, the authors followed the approved classification of economic activities, which is different from priorities of creative economy in Europe, such as music or design, as these areas are not distinguished as separated fields in Lithuania. The main objective of the study is to tackle Lithuania's creative and cultural industries that take their deserved place in the Lithuanian economic life. Based on the Department of Statistics, the authors present companies and a size of their headcount in creative and cultural industries: in 2007, there were 6,149 companies employing 61,297 employees that accounted for $8 \%$ of all companies operating in Lithuania, where the number of employees occupied $4.02 \%$ of all employed people in Lithuania; there were in average 246 new enterprises appearing annually, where the number of employees was increasing by c.a. 1,049 new employees $^{51}$. This indicates that the sector is rapidly developing, has a great potential and needs more employees.

Financial results showed that in 2006 creative and cultural companies' income exceeded the figure of 4 billion LT, and in the period from 2001 to 2006 in average increased by more than 400 million LT annually. It should be noted that these figures exceeded Lithuania's GDP growth rates, where sales accounted for $5.2 \%$ of the Lithuanian GDP in 2006. The net profit of creative and cultural industries in 2006 reached 317 million LT, and every year from 2001 to 2006 increased in average by more than 40 million LT. The growth in both revenue and net profit has been the largest in activities, such as architecture, advertising and publishing.

The labour productivity in 2006 increased by $21.2 \%$, which is one of the greatest labour productivity growth rates compared to other sub-sectors ${ }^{52}$. This shows a huge

Makselis, R., supra note 14.

50 Antanavičiūtè, R., et al., supra note 25.

51 Ibid.

52 Antanavičiūtè, R., et al., supra note 25. 
growth and opportunities in creative and cultural industries to better develop these sub-activities, as the labour productivity increases when work skills of people are improving and modern technologies are in use. Within the dynamics of creative and cultural industries' activities and workforce, the greatest growth in a number of employees in advertising and architecture activities can be witnessed, while the decline in a number of employees is seen in the ceramics and decoration fields.

The sector of cultural and creative industries is a rapidly developing sector, the development of which requires new professionals, new jobs, and there are more opportunities for creative people to realize their potential. However, this study highlights the lack in Lithuania of artistic disciplines, such as film, video, montage, animation, and it is also argued that it is difficult to determine the lack of artists in Lithuania. The authors agree that creative industries, in carrying out their activities, encourage the development of other economic sectors, especially modern technologies, because technologies and the Internet are important factors of growth. The absence of monitoring system, based on economic and social indicators, is identified as a problem of missing the opportunity to find out main needs of creative sectors. The needs of industry and society in developing products, services, knowledge of both scientific and creative environment are not sufficiently taken into account. Turning from sciences, arts and culture to a user, for whom products and services are created, is an essential condition, which should be continuously acknowledged ${ }^{53}$. A modern society is saturated by goods, services, events and activities that become routine in an everyday life, thus, the public is waiting for new and innovative products and/or services.

Habits of a modern society are becoming less material and tend to be related to consumption of cultural goods and/or services as well as understanding that arts and sciences become more important in Europe ${ }^{54}$. It would be wrong to distinguish fashion, dictated by a modern society, as unrelated to the development of products of creative industries, i.e. people, to whom products are created within the creative process, should be involved in their production and evaluation process, otherwise products of creative industries remain misunderstood and face the need to find niches in foreign countries, or their authors emigrate abroad, where their products and skills are assessed and recognized.

\section{Investments and Brokerage in Arts}

The arts market is not only interesting in terms of the reflection of consumers' tastes, emotions or education, but also because it is one of alternative investment instruments, where the investment object refers to creations of arts, thus, the investment portfolio consisting of stocks, bonds and other securities, real estate should be potentially extended by works of arts, precious metals and gems. Investments in 
arts are considered one of the safest investments, because they are least affected by the inflation (or get the inverse correlation, i.e. the cheaper currency makes works of arts more expensive $e^{55}$. Many investors, especially under adverse investment conditions, such as the crisis, refer investments to works of arts. It should be taken into account that these investments are long-term, so speculators are not interested in this market; the return on investment in this market is not large, but gives a much greater security, resulting in psychological stability among the investing in the arts market.

According to the Art Market Agency ${ }^{56}$, in terms of the performance, geographically New York is the market leader in arts, where $46 \%$ of the global arts market is concentrated and the most expensive works of arts are bought in auctions, followed by London with $27 \%$ of the market, Paris with $6.4 \%$ of the market, and China, which is rapidly increasing its share in the global arts market with $4.9 \%$ in 2006. In 2004, among top 100 artists from the Art Price Global Index, Pablo Picasso led in terms of sales volume ( $\$ 240,991,946$, works sold in 1264 auctions). Due to his remarkable productivity and name, Picasso is a longtime leader in auctions: his sales read $6.7 \%$ of global arts market sales ${ }^{57}$, and in 2004 his work "Garçon à la pipe" was sold in the Sotheby's auction in New York (at the 'hammer' price of 93 million \$; the price including taxes reads 104.1 million \$). It is one of the most expensive works ever sold in an auction. Claude Monet took the second place in 2003 (\$80,467,700 for the sale of 25 works), when Vincent Van Gogh had dropped to the 26th place (\$19,473,391 for 6 works).

According to compilers of the Art Price Global Index, in 2006 there was a decrease in a number of auctions registered (2000 - 15000, 2005 - 9600, 2006 - 9200 auctions per year), but the number of works of arts sold is growing and there is an increase in very expensive works of arts witnessed (in 2006, 810 works sold, valued of over $\$ 1$ million, generating in total over the 2.7 billion $\$$ turnover). The Art Price Global Index ${ }^{58}$, compiled in 2006, presents top 10 artists, whose works' value reads over 59 million \$ for one work: Pablo Picasso stands at 339,245,929 \$, Andy Warhol reaches 199,392,442 \$, Gustav Klimt marks 175,143,589 \$ sales, etc. Looking at the Lithuanian market, it can be safely assumed that it is very distant from the world, where the main arts galleries, auctions and dealers are listed. While working with artists, galleries exhibit their works creating their name and giving an opportunity to be famous, because talent alone is insufficient, while already-known artists' names are sold in auctions. Thus, the Art Market Agency ${ }^{59}$ draws attention to the fact that artworks are sold from hand to hand in Lithuania, i.e. privately, and this prevents from the formation of the arts market, as an acquired work is not officially declared, and taxes are not paid for acquisition, so there is no guarantee and liquidity; in addition,

55 Meno rinkos agentūra. Investavimas ị meną: Ar jau laikas? Vilnius, b.m. 2007.

56 Ibid.

57 Ibid.

58 Meno rinkos agentūra, supra note 55.

59 Ibid. 
artists that sell their works themselves are not sure if the offered price is right, while a buyer is not sure whether he/she overpays for a work or not.

Lithuania lacks data to build indices of Lithuanian artists, because there is no accounting system implemented of actually sold and purchased works ${ }^{60}$. This goal is intended to be achieved, as with the arts index it will be much safer and easier to invest in works of arts. Meanwhile, it is clear that their main concerns are related to funding opportunities, and, as artists themselves state, the opera, classical find funding music much easier than other areas of culture; it could be related to a fear of business risk and a relatively weak knowledge of contemporary culture.

According to businessmen, to attract global names to Vilnius is risky due a risky public, because even the country's elite does not always know world-famous artists, such as the Italian director Castellucci, "but the presence of the elite and development trends in the arts market create a smart, modern, discerning corporate image", which was stated by the director of Sirens Budraitis, in 2011. Businessmen better than anyone else know that a higher risk means higher returns, but it is regrettable that the Lithuanian elite and contemporary artists earn only from tours, festivals (e.g., the theater of Oskaras Koršunovas or Eimuntas Nekrošius), as to display plays in Lithuania is a disadvantage. Lithuanian artists believe that cultural education of the public and elite events should get more attention from the side of big businesses, because the perception of culture and taste could be trained.

Artists' recognition in the arts market is one of the most important aspects of their creative life, which comes through the need to display works publicly via the critics and attraction of private collectors (via exhibitions, galleries). It is correct to state that the number of artists whose work reaches a high-level recognition and high prices is limited. The results of the "Taste Buds"61 study in England identified four types of artists: recognized artists, progressive artists, emerging artists and a vast majority of artists. The need to create is greater than the need of living from creations as well as assessing works of artists that go to other hands. Artists who do not seek reputation sell their own creative work to casual customers, and vice versa, those seeking recognition sell to arts galleries, collectors, etc.

A general trend is that many artists do not have necessary knowledge on the arts market. It was observed in England in 2004, where $60 \%$ of artists declared lacking managerial skills. The "Taste Buds" ${ }^{\prime 2}$ research revealed that $26 \%$, i.e. 10.2 million, citizens of England wanted to buy an original work of arts, and it is more likely to be a woman than a man, and they will be university-educated people. This study also revealed a relentless collectors' passion, since acquisition of works of arts defines their position in the society, meets intellectual needs, emphasizes their individuality and allows them to be proud of knowing famous artists.

60 Meno rinkos agentūra, supra note 55.

61 Morris, H. M. Taste Buds: Taking Part in the Arts. 2004.

62

Ibid. 
Contemporary arts buyers purchasing works of arts begin from classics, clear works and only after getting a better understanding, taste and experience acquire innovative contemporary works. Other reasons why contemporary works are not purchased is the feeling belonging to a lower class and the limited financial capacity; hence, these buyers tend to buy reproductions, while potential buyers want to get more information where and how to buy art works and how much to pay for them. A very important aspect of the arts market becomes the protection by copyright, while arts-business brokers help to protect these rights, to build business and to penetrate the market.

Good practices in different countries show that creative industries are encouraged by the development of arts incubators. Various artists and arts-related businesses concentrating on one area, enabling to develop and publicly present works, to develop already existing arts-related businesses or creating new ones, are described as arts incubators. "The arts incubator is an organization centred on its premises for small and medium businesses, starting businesses or arts-related businesses", as it was stated by ${ }^{63}$. In the seventies of the twentieth century, creative studies in nontraditional spaces became popular, i.e. depopulated factories known as lofts. The most of such informal spaces were perfect spaces for informal troupes that prepared social performances. In 1998, the first State funds-dependent theatre "Meno fortas" (English - The Fort of Arts), the existence of which was based not on the theatre palace, but on the theatre idea, was founded by Nekrošius and Šaltenis. In 2009, Imbrasas established "Menų spaustuvè" (English - The Arts Printing House), representing modern performing arts projects, which was established in the Exhibition Hall: two auditoriums, rehearsal room and infotek of the Vilnius Academy of Arts. These stages are the places for modern dance projects, theatre and stage debuts. The stages also were places for festivals, such as "Sirens" and "New Drama Action". It is believed that being located next to each other The Fort of Arts and The Arts Printing House are probably the most successful creative industries project in Lithuania, because young artists get more experience. Contemporary theatre is interrelated with technologies, as a rare spectacle could do well without a special light, video or sound effects, and directors implement their ideas through innovations and education of the society.

Offering attractive prices, arts incubators rent premises (for working, display of works or realization), office equipment, provides technical, advisory, training and other services as well as organize events, compile and analyse information on creative industries, and all these services for incubated entrepreneurs are at a lower than the market price. Thus, the main purpose of arts incubators is to support artists and start educating the younger generation, to reduce operational risks, promote job creation, when financially weak firms or individuals having great creative ideas are helped to achieve self-sufficiency in their operations. According to the Feasibility Study carried out in Lithuania, since 2008, “a vast majority of businesses leaving incubator facilities 
and settling successfully continue to develop their creative activities in a local environment" ${ }^{\prime}$. Thus, arts incubators and parks combine creative activities, open the exchange of knowledge and information opportunities, establish partnership opportunities among sciences, creative activities and businesses; they help new talents to grow while creating more favourable conditions for artists to exhibit their work, start their businesses, become entrepreneurial and promote participation in a cultural life.

Lithuanian cities already possess active incubators, such as the Creative Business Incubator of Arts Printing House, the Užupis Arts Incubator or Telšiai Arts Incubator and informal arts incubators, such as the ones in Klaipeda, Kaunas, Šiauliai and Anykščiai. However, authors of the Lithuania's Feasibility Study (2008) state that arts and science incubators are established only thanks to European Union Funds, thus, in practice a vast majority of science and arts incubators/parks are only at the stage of developing physical infrastructure or building theoretical conceptions, as fullyfledged incubators/parks are not functioning in the market. This study points at the fact that existing incubators'/parks' activities should focus on developing the 'hard and soft' infrastructure, i.e. communication, flexibility, technology, etc. In 2006, there were only rental and maintenance of technical base and facilities observed in Lithuania, thus, the country lacks qualified administration and management employees, while their personal interests and reluctance to give up the space for new initiatives, ideas are visible; there are experts' and professionals' needs, the lack of lobbying power as well as the need of public and private capital identified.

Therefore, trainings and qualification development seminars for the arts incubators' and parks' personnel, including psychologists' and sociologists' advices are necessary to achieve the integration among arts, sciences and businesses. Artists consider freedom, uncertainty or personality-oriented features as values, while the business world focuses on material values. These two different worlds cannot easily find a common language; therefore, the inclusion of psychologists and sociologists is crucial to promote the growth of an incubator. It is also proposed to organize students' practice incubators and large (700-3000 sq. m) or small (100-500 sq. m) incubation systems.

While supporting and encouraging the creativity, new artists' ideas and their implementation in both arts incubators and clusters emerge as important means of taking care of cultural and creative activities in various spheres (ecclesiastical, educational, literary, art works, etc.). The term 'patron' comes from the name of the Emperor Augustus' friend Mecenas, who in the ancient Rome supported writers. It is stated that the first Lithuanian patrons were the Radvilas, the Oginskis, the Tiškevičius and the Tyzenhauzas families. They supported construction of churches, libraries and archives, supporting theatres, manor musicians and artists, and artists' scholarships for studies abroad. 
Creative industries do not only create a significant economic value, but also encourage other areas of economic development ${ }^{65}$. One of such examples is clusters that are businesses with a variety of talents and competencies that complement each other, concentrated around one geographical spot. These groups are more open to innovations, including new technologies or developing urban images. The emergence and dissemination of art works in the society correspond to a public policy and public interests of the society, as they contribute to arts and cultural development ${ }^{66}$. Companies, whose activities are related to the creativity, such as music, fashion, visual arts, design, film, etc., have been merged into separate clusters, reflecting the economic, social and cultural interaction, and this development is a crucial for business survival and companies' growth, as it is the means of economical work, getting advantages in the labour market, receiving more innovative information and knowledge.

The publication "Ice-Free Culture, 2006/2008" (Lithuanian - Neužšąlanti kultūra) draws attention to cluster development as a positive initiative for different sectors and different industries to come together for a common goal; while the music industry is a good example of cluster, because there is a wide range of businesses that work together to enhance the overall competitive impact on the market. In 2005 mapping creative industries of Utena's and Alytus' counties, there was conducted a survey on creative industries workers' skills, the results of the survey showed that most of these workers lack social and communication skills, i.e. management, ability to communicate, cooperate, attract sponsors, organizational abilities. Thus, Mažeikis and Makselis conclude that at the current stage of development communication, knowledge, social networks, community involvement, information dissemination, development of infrastructure are equally important for helping local businesses to understand the potential of the creative sector and investment benefits ${ }^{67}$.

The model of the Alytus Trade School is presented as one of the broadest social network providers. This type of cultural development happens in many parts of the world, for example, in Sigchos city of Ecuador artisans produce clay utensils and weave clothes using authentic ornaments and colours, or, as in Syria, there are small businesses under the old tradition of soap manufacturing coming together. Such clustering serves not only a purpose of protection against unauthorized copying of goods, but it also states a respect for standards and investment opportunities.

Various creative economic sub-sectors have their specific needs; however, from a certain perspective, small representatives of creative industries, such as music bands, face various needs and problems that are harder to solve being small. Clusters bring together individual creators, optimizing individuals' functions and potential. Clusters can develop spontaneously or they can be designed for a particular purpose, because they can cover a range of industries, hence, they contribute to the cooperation among

65 Makselis, R., supra note 15.

66 Ibid.

67 Ibid. 
different sectors or development of creative industries parks in different geographical locations (Barcelona, Shanghai, etc.). The development of a cluster is important for bringing, encouraging, supporting, motivating, representing creative industries, because it contributes to cognitive needs of the sector by attracting necessary investments.

Creative industries are based on intellectual property, thus, it is becoming important to have a relevant law and intellectual property protection requirements associated with cultural activities, creative services and products. Developers can be effectively protected via intellectual property management, which encourages the creativity. Towse ${ }^{68}$ in his work "Creativity, Copyright and Creative Industries Paradigm" tackled both the work in the creative economy and creative industries and the copyright as an economic stimulus. He stated that "The Copyright law is not only a legal framework; it is also associated with moral rights, rights of excellence, integrity, identification and elimination of a protected work" 69 . Some emerging economies, such as Asia, Latin America or African countries (Algeria, Ghana, Kenya, Namibia, Zambia and others), have adopted laws to protect an intellectual property. Yet, in many developing economies, the copyright protection of creative economy products is weak or non-existent. Although copyright protection systems exist, there are still frequent inspection and/or management problems, as it was said in the study "Creative Economy"70.

Piracy (copyright infringement) is a serious challenge for a number of developing economies. African 'piracy' is one of the main reasons why artists from Africa have lost the opportunity to develop their careers and to make creative industries viable. There is a reason to believe that copyright infringers have competitive advantages in the music industry, mainly because their prices are lower, they need less investment, and they have close ties with unofficial, but very productive distribution channels, and even sometimes collaborate with individual artists, who want to enlarge their audiences. Unsolved issues related to the copyright and tax system lead artists to their priorities of live performances, larger income and more efficient advertising.

\section{Methodology}

The decision of choosing a qualitative research method was driven by willingness to achieve the accuracy of results, as a qualitative method is mainly based on respondents' views; it enables researchers to easily collect and use data for analysis while comparing respondents' thoughts. The present study of Lithuanian fashion design is based on interviews' questionnaires in order to assess fashion designers' management capabilities and characteristics. The descriptive qualitative study was

68 Towse, R. Creativity, Copyright and the Creative Industries Paradigm. Kyklos. b.v. 2010, 3: 461-478.

69 Ibid., p.2.

$70 \quad$ United Nations. Creative Economy, supra note 24. 
selected, carried out once and not repeated. There were semi-structured interviews used providing the opportunity to receive a deeper and vaster interpretation of respondents' answers. The research results cannot be summarized as the consensus of all designers, since the selected study sample is made by using a convenience sampling method.

The interviews were conducted within 29 days, i.e. from 24th March, 2011, to 21st April, 2011. The semi-structured interviews were initiated during the festival "Fashion Infection" and later by personally contacting the fashion designers by e-mail and/or telephone and agreeing on a mutually suitable meeting time and location. To get the opportunity to meet the costume design Master students at the Vilnius Academy of Arts, it was referred to the administration staff of the Costume Design Department. The questions were asked directly to respondents by reading and clarifying them, if necessary. Thus, the respondents were given the opportunity to formulate more accurate answers, while the investigator had the possibility to carefully record their answers.

There was a sample size of 20 fashion designers set, 10 of them were well-known Lithuanian fashion designers and 10 Lithuanian fashion designers who had recently completed their studies and/or still studied at the graduate program of the Costume Design Department at the Vilnius Academy of Arts. There were 17 well-known fashion designers contacted, while 7 designers refused to participate in the survey, as the main refusal reason was the lack of time because of new clothing collections. This is a good result considering the fact that interviews are time-consuming, and fashion designers do not in general agree to participate in such researches.

The questionnaire was set out in the sequential order. Firstly, interrogators presented themselves (International Business School researchers), then the objective of the study was specified, and confidentiality/discretion was emphasized. There were open-ended questions used, because such type of questions allows more interpretation, and personal interviews guarantee avoidance of mistakes. Researchers can always ask respondents to clarify a response or his/her argument. Closed-type questions in the questionnaire were related to demographic characteristics, as such questions are easier to statistically process since only one answer is possible. The collected interview data was processed and analysed by describing and interpreting responses to questions.

Most of the respondents were 18-25 years old. The second largest age group was respondents of 26-35 years old. The Master students at the Vilnius Academy of Arts, the Department of Costume Design, formed the largest group of respondents, while the well-known designers equally belonged to the age groups of 18-25 years old and 46-60 years old. It becomes clear that the majority of the respondents have achieved or are pursuing higher education (those, who already have a Bachelor degree). This trend may be compared to the Eurostat (2007) data, where in many European Union member states more than $60 \%$ of employees in the cultural sector have completed university education. 9 of the interviewed well-known Lithuanian fashion designers had higher education. 


\section{Management Peculiarities in Lithuanian Fashion Design Companies}

The first group of questions aimed at finding out whether respondents had their own business or not. The research results showed that four well-known Lithuanian fashion designers had their own business (one man and three women); the remaining six did not have their own business. A vast majority of students did not have their own business: only one respondent owned a business (a woman of 26-35 years old with higher education completed). Following a negative response that the respondents did not own their business, there were answers to the questions regarding the type of work a respondent was employed in (random or short-term) and the type of a contract (fixed, unfixed, authorship) scrutinized (see Figure 2).

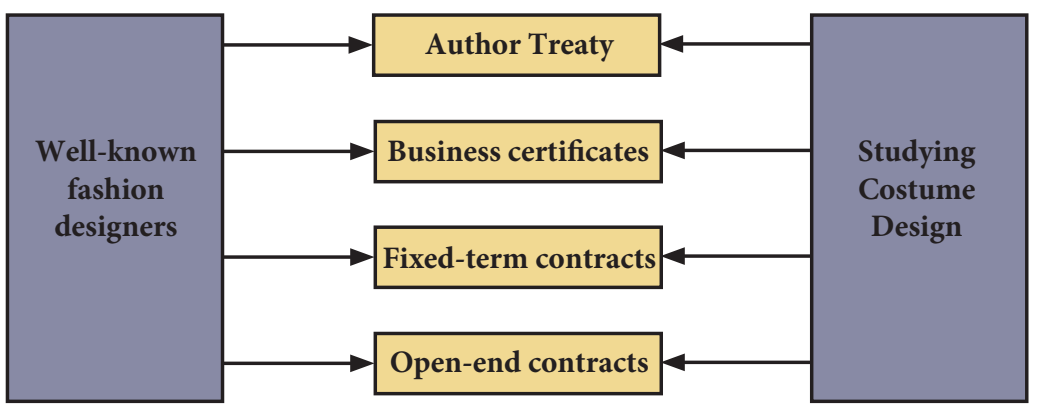

Source: prepared by the authors, 2011

Figure 2. The legal status of activities, based on the frequency

All the interrogated well-known fashion designers who did not own business worked at random short-term jobs, and these jobs are often legitimated by authorship treaties; the second most common form was business license, followed by fixedterm contracts for specific projects, and the least had an indefinite status, i.e. 1 respondent had a permanent job as an employee (male, 36-45 years old with higher education). Among students, eight of them worked at random, short-term works, whereas one worked under a permanent contract (a woman, 18-25 years old with higher education); authorship contracts were often enacted among this group of respondents. Being asked whether they would like starting his/her own business, both famous designers and a vast majority of students answered that they would like to have their own business (see Figure 3). 


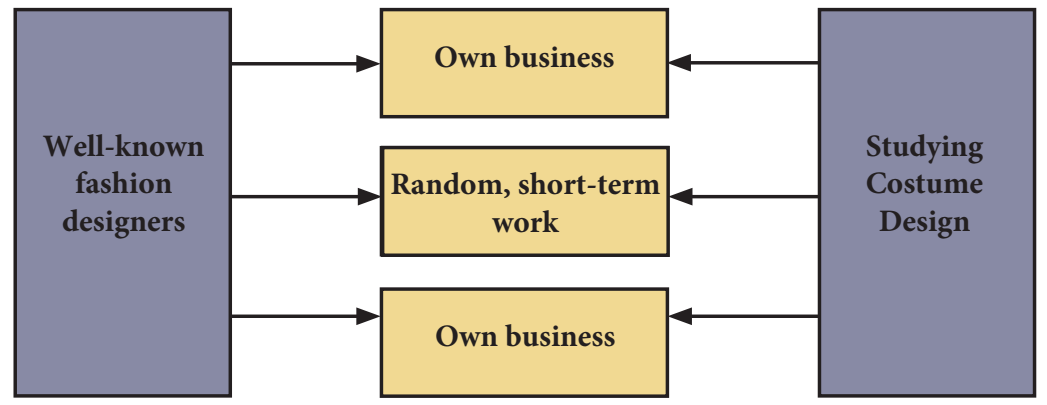

Source: prepared by the authors, 2011

Figure 3. The distribution of activities

Although it can be concluded that both the well-known Lithuanian fashion designers and costume design students dream of setting up their own business, currently only a small proportion of respondents own their business. Both groups are united by the fact that they usually work under authorship contracts, followed by permanent and fixed-term contracts to execute one-off projects, and the difference between these groups is that none of students have a business license.

The second group of questions focused on the respondents having their own businesses. These questions were intended to find out when, how, with what resources, what businesses had been established, and whether the respondents felt support for creation and/or development of their businesses. While analysing the respondents' answers, the two groups (the known fashion designers and students) were not analysed separately due to a small number of respondents having their own business. The analysis of answers showed that most of businesses were developed in 2008. This could be associated with the second largest age group of 26-35 years old, because these creators have already graduated from higher education and possess a considerable experience in their business.

Answering to the question whether a business was created by trusting another person, the majority of respondents admitted that they created their business alone; one respondent trusted a family member, while other businesses were created in conjunction with a partner. The co-ownership was mentioned only by one respondent; however, after two years he/she demerged and since then was the owner alone. All remaining respondents owned their business themselves; several respondents indicated that they intended to expand and did not refuse the possibility of acquiring a partner company. All respondents pointed out at personal savings as the main resource for establishing business, some of them added loans from banks because of insufficient personal savings. Some of the respondents used resources only for purchasing equipment, because they already had their own premises; other searched for premises for business development (purchased, rented). Four businesses 
having respondents did not feel any governmental support while developing their businesses; one respondent claimed idem; however he/she perceived possibilities and intentions to use it. Another respondent having his/her business for many years argued that fashion designers had never been supported by the government, and that any attempt to find out about public assistance ended up with higher taxes (see Figure 4).

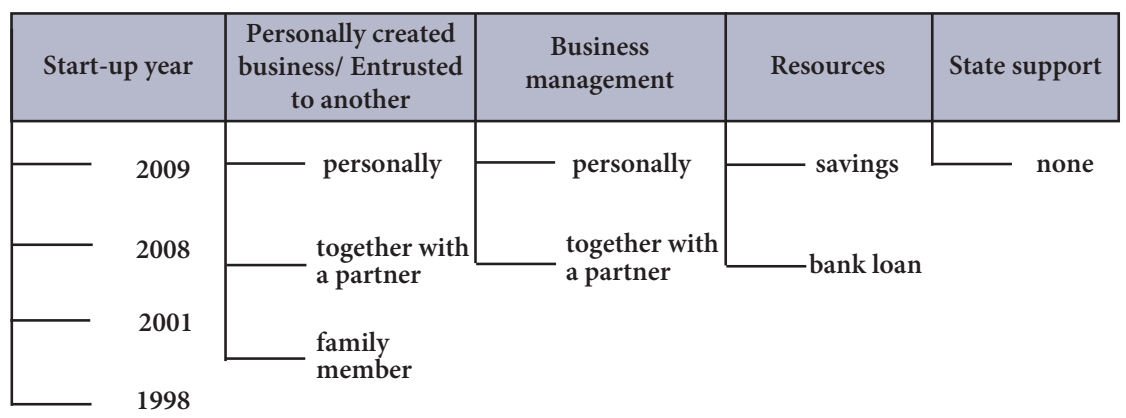

Source: prepared by the authors, 2011

Figure 4. Business creation and management

To summarize the above mentioned facts, it can be stated that fashion designers do not rely on other people while starting-up their businesses and create it themselves from their own resources (savings); while the state support and/or assistance in creating and developing business is not positively evaluated by creative industries' developers, who are disappointed with the government's attitude towards creators.

The third group of questions was to examine peculiarities of fashion designers' work, i.e., principles of creation, delivery, marketing and selling their works. The analysis of responses to the question whether fashion designers work individually or in groups showed that it greatly depended on what was being created, i.e. whether it was a personal collection of clothing, a one-off project or ongoing work. While organizing a work process, sales and presentations of collections, it is important to acknowledge if fashion designers take care of their business themselves or entrust other professionals to realize these objectives. It turned out that there was no common 'formula': these processes were controlled by designers themselves and, if necessary, they demanded for assistance of professionals. Though designers who worked in groups allocated some tasks to employees, they still needed to pay considerable attention to these activities themselves, i.e. designers needed to control actions performed by employees, and only one fashion designer had a team of a competent staff for a successful development of his/her business and co-operated with publicity agencies. While intending to find out how it was possible to buy fashion designers' clothes, the most common answers received were "contacting personally" or "arriving at the studio", because clients of fashion designers who presented their work in boutiques after the bankruptcy of these shops did not have other choice than 
"contacting personally"; however, some designers were marketing clothes in their shops and online stores, and, as the alternative to the previously listed answers, some fashion designers underlined the opportunity to use Facebook to sell their creative works (see Figure 5).

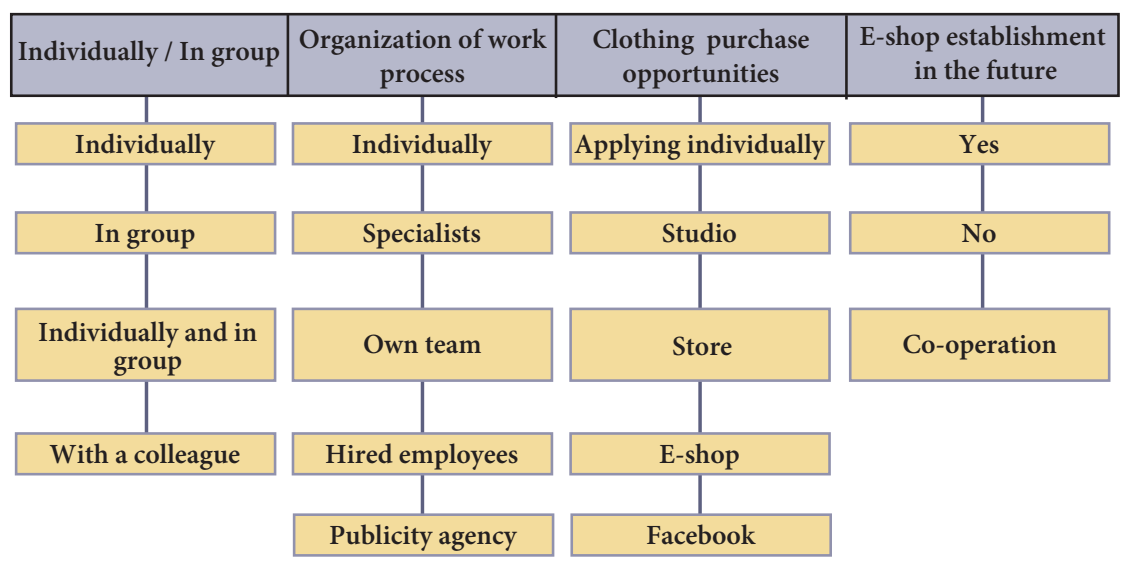

Source: prepared by the authors, 2011

Figure 5. Business process organization, according to the importance

Answering to the question whether fashion designers would set up their e-shop, the majority expressed their intentions, and only one fashion designer did not intend to set up a personal e-shop, but in collaboration with other fashion designers planned to present his/her clothes to the market in this way. The fourth group of questions sought to determine whether Lithuanian fashion designers' works were presented in fashion weeks or other similar events abroad, and whether they collaborated with designers from other countries and/or Lithuanian designers, other businesses, educational institutions, etc. The study showed that more than half of fashion designers presented their works in other countries, but, according to one of them, "any expansion to foreign markets costs too much and without larger investments (sponsors and State support, etc.) is almost impossible to get access to other markets." Some fashion designers already worked on new plans how to start their own business in foreign countries and all investigated London, which is the centre of attraction of creative industries' representatives. The presentation of collections and setting up their businesses in other countries were intended by all the fashion designers, because the larger the market is, the greater the recognition, income, ability to create, expand by using the edge technologies and developing are.

In the process of development, delivery, sales, only one fashion designer did not cooperate with other representatives of creative industries and market players, while others tried to collaborate with designers, educational institutions, businesses and 
other representatives of creative industries, because it is very important to increase the awareness of their activities and creations, to promote fashion design closer to the public and dissemination of knowledge in this sector (see Figure 6).

\begin{tabular}{|c|c|c|c|c|}
\hline $\begin{array}{l}\text { Work presentation } \\
\text { in other countries }\end{array}$ & $\begin{array}{c}\text { Communication } \\
\text { with other } \\
\text { countries' creators }\end{array}$ & $\begin{array}{c}\text { Communication } \\
\text { with other market } \\
\text { players }\end{array}$ & Co-operation & $\begin{array}{l}\text { Competition in } \\
\text { Lithuania }\end{array}$ \\
\hline Yes & Yes & Yes & Other artists & Yes \\
\hline No & No & No & Enterprises & No \\
\hline$\downarrow$ & & & Photo studio & Sometimes \\
\hline Would they like to... & & & Theaters & \\
\hline \multirow[t]{3}{*}{ Yes } & & & Journals & \\
\hline & & & Advertisement & \\
\hline & & & Events & \\
\hline
\end{tabular}

Source: prepared by the authors, 2011

Figure 6. Cooperation, partnership, competition in terms of frequency

Within the development of creative activities, almost all the fashion designers not only created personal collections, but also co-operated with companies and institutions that run various activities; as it was said by one fashion designer, "we are doing everything in cooperation with other artists, photo studios, magazines, theatres, advertising companies, event's organizers, etc.", and "only one fashion designer who is the only fashion designer creating his/her personal collections, because he/she thinks that Lithuania is too small to establish business, because clothes for theatre performances and various events are created by the same fashion designers", thus, to get into this business, according to the respondent, is impossible.

\section{Conclusions}

Countries that develop their creative industries perceive these sectors not only as a marketing means of a country, but also as an economic development, investment potential, social inclusion, development of innovations as well as direct contributions to GDP. A significant proportion of creative workers in Lithuania do not evaluate their activities in terms of economic efficiency; too little attention is paid to marketing, resulting in a relatively low competitiveness of creative products and services.

Within the global market, the largest contribution to the trade balance in creative goods and services is made by design products that have been taking the leading position among other creative industries subgroups; the arts crafts industry 
is the only creative industry, according to which the developing economies take the leading position in the international market. The international trade in music, visual arts is dominated by the developed economies. In 2008, the United States of America took the leading position among the developed economies in terms of creative industries in all groups, while the developing economies were led by China, Latin America (Mexico), the Caribbean (the main exporter is the Dominican Republic), Africa (Egypt). Within the service sector, the leading position among the developed economies is occupied by the United States, and among emerging economies Turkey, Malaysia and India take the lead.

The Lithuanian fashion design sector is on the right track in increasing the market openness and accelerating the market dynamics, as both the well-known Lithuanian fashion designers and costume design students dream of setting up their own business. However, the fashion designers do not rely on other people while starting-up their businesses and create it themselves from their own resources (savings), while the State support in creating business is not positively evaluated by creative industries' developers. On the other hand, within the process of development, delivery, sales, only one fashion designer does not cooperate with other representatives of creative industries or market players. Others try to collaborate with designers, educational institutions, businesses and other representatives of creative industries, because it is important to increase awareness of their activities and creations, to promote fashion design and dissemination of knowledge in this sector.

Although expansion to foreign markets is considered as costly and risky, some fashion designers already have started their business in foreign countries (a majority of them focus on London). The fashion designers admit that the larger the market is, the greater are recognition, incomes and abilities to create and expand by using edge technologies. Hence, to mitigate the unfavourable effect of a small market, the Lithuanian fashion designers should acknowledge the role of cyber business, digital marketing as well as co-operation possibilities with fashion designers from neighbour countries. In their business, "big is not always beautiful", because the quality, innovativeness and talents can all lead to stronger competitive advantages and higher incomes.

\section{References}

Antanavičiūtè, R.; Gelūnas, A.; Juodelienè, A., et al. Lietuvos kūrybinès ir kultūrinès industrijos. Galimybiu studija [interactive]. Vilnius. 2008, p. 91 [accessed on 2010-11-23]. <http://lmta. lt/web/pdf/>.

Burckhardt, J. Civilization of the Renaissance in Italy. Random House Publishing Group, 1995, p. 432.
Caves, R. E. Creative Industries: Contracts between Art and Commerce [interactive]. Harvard, 2001, p. 19 [accessed on 2011-02-10]. <http:// www.google.com/books $>$.

Colmer, J. E. M. Forster: The Personal Voice. Routledge, 1975, p. 243.

Creative \& Cultural Skills. Creative and Cultural Industries: Key Facts 
[interactive]. UK, b.m. 2010 [accessed on 2010-11-16]. <ttp://www.ccskills. org.uk>.

David, P. A.; Foray, D. An Introduction to the Economy of the Knowledge Society. International Social Science Journal. 2002, 54 (171): 9-23.

Department for Culture, Media and Sport UK. Creative Industries Economic Estimates [interactive]. 2010 [accessed on 2010-11-19]. <http://www.culture. gov.uk/publications/6552.aspx $>$.

Department for Culture, Media and Sport UK. Creative Britain - New Talents for the New Economy [interactive]. 2008 [accessed on 2010-11-19]. <http:// www.culture.gov.uk/publications/ 6552.aspx>.

Eikhof, D. R.; Haunschild, A. Lifestyle Meets Market: Bohemian Entrepreneurs in Creative Industries. Creativity and Innovation Management [interactive]. 2006, 3 (15): 234-241 [accessed on 2010-11-20]. <http://web. ebscohost.com>.

European Commission. Eurostat. Office for Official Publications of the European Communities. Population and Social Conditions. Cultural Statistics [interactive]. Luxembourg, 2007, p. 185 [accessed on 2010-1126]. <http://epp.eurostat.ec.europa.eu/ cache/ITY_OFFPUB/KS-77-07-296/ EN/KS-77-07-296-EN.PDF>.

Florida, R. The Rise of the Creative Class: And how It's Transforming Work, Leisure, Community and Everyday Life. New York: Basic Books, 2002, p. 404.

Gray, Ch. M.; Heilburn, J. The Economics of Art and Culture [interactive]. Cambridge: University Press, 2001, p. 1-10 [accessed on 2011-11-12 November]. <http://catdir.loc.gov/catdir/ samples/cam031/00059875.pdf >.

Levin, J. Bohemia in America, 1858-1920. Stanford University Press, 2010, p. 469.
Lietuvos Respublikos kultūros ministerija. Kürybiniu industriju skatinimo ir plètros strategija [interactive]. Vilnius, 2009 [accessed on 2010-11-15]. <www. lrs.lt>.

Makselis, R. Lietuvos kultūros įstaigų valdymas kūrybinių industrijų plètojimo pagrindu. Šiuolaikinis kultūros ìstaigų administravimas ir valdymas [interactive]. Vilnius, 2007, p. 93-130 [accessed on 2010-11-27]. <http://www.lkdtc.lt/_ download/mokomedz/01_Makselis. pdf $>$.

McNeilly, M. Sun Tzu karo menas lyderiams. Pergales strategija. Kaunas, 2007, p. 248.

Meno rinkos agentūra. Investavimas $i$ meną: Ar jau laikas? [interactive]. Vilnius, 2007 [accessed on 2010-1118]. <http://www.menorinka.lt/index. php?cid $=40>$.

Morris, H. M. Taking Part in the Arts: Taste Buds [interactive]. 2004 [accessed on 2010-11-18]. <http://www. takingpartinthearts.com/content. php? content $=1034>$.

Neužšalanti kultūra. 2006/2008, Klaipėda. Klaipèdos universiteto leidykla. 2008. p. 86.

Panofsky, E.; Heckscher, W.S. Three Essays on Style. Cambridge: MIT Press, edited by Irving Lavin, 1997, p. 245.

Parrish, D. Marškinèliai ir kostiumai. Kūrybinio verslo vadovas [interactive]. Liverpool, 2005 [accessed on 2010-1220]. <http://www.koperator.lt/lt/55 8382/kik_industrijos/david_parrish_ e.knyga $>$.

Rimkutè, A. Kultūros politika ir kultūros industrija: tradicinis santykis ir nauji iššukiai. Respectus Philologicus. Central and Eastern European Online Library [interactive]. Vilnius, 2009, 15 (20): 6275 [accessed on 2011-11-12]. <http:// server.uzupiozinios.lt/kurybinesindustrijos/?p=199>. 
Starkevičiūtè, M. Kürybiniu ekonominiu veiklu indelio $i$ Lietuvos ekonomika ìvertinimas. Europos kultūros programos centras. Britu taryba [interactive]. Vilnius, 2003, p. 25 [accessed on 201011-15]. <http://www.uzupiozinios.net/ Docs/M_Starkeviciute.doc>.

Towse, R. Creativity, Copyright and the Creative Industries Paradigm. Kyklos [interactive]. b.v. 2010, 3: 461-478 [accessed on 2011-02-19]. <http://www. acei2010.com/upload/acei/towse.pdf $>$.

United Nations. Creative Economy. Report 2008. UNCTAD/DITC [interactive]. b.v., 2008 [accessed on 2010-11-16]. <http://www.unctad.org/en/docs/ ditc20082cer_en.pdf $>$.

United Nations. Creative Economy. Report 2010. UNCTAD/DITC/TAB [interactive]. 2010 [accessed on 201101-22]. <http://www.unctad.org/en/ docs/ditc20082cer_en.pdf $>$.

Van den Berk, T. Jung on Art: On the Autonomy of the Creative Drive. Routledge, 2012, p. 176.

Wolfflin, H. Classic Art: An Introduction to the Italian Renaissance. London: Phaidon, 1994, p. 294.

\title{
KŪRYBINIŲ INDUSTRIJŲ PLĖTRA: LIETUVOS MADOS DIZAINO IMONIŲ ATVEJIS
}

\author{
Mindaugas Laužikas, Rasa Mokšeckienè \\ Vilniaus universiteto Tarptautinio verslo mokykla, Lietuva
}

Santrauka. Kürybines industrijas vystančios šalys šiuos sektorius vertina ne vien kaip rinkodaros, šalies ivaizdžio kūrimo priemone, bet ir kaip ekonominès plètros, investicijų, bendro vidaus produkto kūrimo šalyje galimybę. Vis dèlto nedaugelis kūrybiniu industriju atstovu geba vertinti savo veiklos efektyvumą, pristatyti savo kürinius vartotojams bei stiprinti kürybiniu imoniu konkurencinius pranašumus.

Lietuvos mados dizaino sektorius sèkmingai vystosi didejjančio rinkos atvirumo ir spartejjančios dinamikos salygomis. Tiek tyrime dalyvavę žinomi mados dizaineriai, tiek kostiumo dizaino studentai trokšta ịurti nuosava versla. Vis dèlto mados dizaineriai nepasikliauna kitų žmoniu pagalba, kurdami versla, ir naudojasi savo santaupomis, o valstybès pagalba kūrybiniam verslui, respondentu nuomone, yra nepakankama. Kita vertus, dizaineriai bendradarbiauja su kitais kürybiniu industriju atstovais, kitu ükio sektorių organizacijomis ir švietimo institucijomis, vystydami versla, tiekdami ir pristatydami produkcija, parduodami bei reklamuodami savo prekes ir paslaugas. Tarporganizacine pagalba yra itin svarbi, stiprinant kūrybiniu industrijų ịvaizdi, konkurencingumą, žiniu sklaida bei užtikrinant efektyvų prekių ir paslaugu pristatymą.

Nors tarptautine kürybinio verslo plètra yra rizikinga ir reikalauja papildomu finansiniu ištekliu, kai kurie tyrime dalyvavę mados dizaineriai jau plètoja versla užsienyje (populiariausias miestas - Londonas). Mados dizaineriai pabrěžia rinkos dydžio svarba pripažinimui, pajamoms bei galimybèms kurti ir plèsti veikla, naudojant modernias technologijas. Siekiant sumažinti nepageidaujama mažos rinkos efektą, Lietuvos mados 
dizaineriai turètu daugiau integruoti savo versla i elektronine erdvę, naudoti elektroninès rinkodaros priemones, glaudžiau bendradarbiauti su užsienio kolegomis, neužmiršdami, jog kürybinèse industrijose kokybè, novatoriškumas, talentai gali sèkmingai kompensuoti organizacijos dydžio ir ištekliu ribotumą.

Reikšminiai žodžiai: plètra, kūrybinès industrijos, mados dizaino įmonés.

Mindaugas Laužikas, Vilniaus universiteto Tarptautinio verslo mokyklos docentas, ekonomikos mokslų daktaras, Lietuvos verslumo stebėsenos (GEM) lyderis. Tyrimų sritys: nacionalinès inovacijų sistemos, verslumas, žinių sklaida, inovacijų ir žmogiškųjų išteklių strategijos.

Mindaugas Laužikas, Vilnius University International Business School, Associate Professor, Doctor of Economics, Leader of Global Entrepreneurship Monitor (Lithuania). Research interests: national systems of innovation, entrepreneurship, knowledge diffusion, innovation and human resource strategies.

Rasa Mokšeckienė, Vilniaus universiteto Tarptautinio verslo mokyklos tyrẻja. Tyrimų sritys: meno ir verslo simbiozės problematika.

Rasa Mokšeckienė, Vilnius University, International Business School, Researcher. Research interests: cooperation between arts and business. 